\title{
PENGARUH PENAMBAHAN FLY ASH, DODOL PLASTIK, MILLE SCALE DAN SUPERPLASTICIZER TERHADAP KUAT LENTUR BETON
}

\author{
Tri Yuhanah ${ }^{1}$, Devita Mayasari ${ }^{2}$, dan Budi Wicaksono ${ }^{3}$ \\ ${ }^{1}$ Sekolah Tinggi Teknik - PLN \\ ${ }^{2}$ Sekolah Tinggi Teknik - PLN \\ ${ }^{3}$ Sekolah Tinggi Teknik - PLN \\ E-mail : triyuhanah@gmail.com
}

\begin{abstract}
Concrete is one of the most common construction materials used for road pavement. In pavement concrete roads are required to have good flexural strength, providing sufficient comfort for drivers and durability. To answer the demands, it is necessary to conduct research and experiment, one of the ways is by using added materials (admixture). This study aims to determine the effect of the addition of fly ash, plastic dodol, mille scale and superplasticizer to the flexural strength of concrete. Concrete is planned with $f_{c} 29.05$ or K350 with fly ash as much as $10 \%$ of cement weight, plastic waste dodol waste $0.15 \%, 0.25 \%$ and $0.35 \%$ of sand weight, $5 \%$ mill scale of weight of sand and superplasticizer as much as $2 \%$ of the water weight. Testing sample at age 7, 14, 28 days, to know compressive strength and flexural strength by converting from result of tensile strength of concrete and absorption.
\end{abstract}

Keywords: Concrete Pavement, Superplasticizer

\begin{abstract}
ABSTRAK
Beton adalah salah satu bahan konstruksi yang telah umum digunakan untuk perkerasan jalan. Dalam perkerasan jalan beton dituntut agar mempunyai kriteria kuat lentur yang baik, memberikan kenyamanan yang cukup bagi pengendara dan keawetan. Untuk menjawab tuntutan tersebut perlu dilakukan penelitian dan percobaan, salah satu caranya dengan menggunakan bahan tambah (admixture). Penelitian ini bertujuan untuk mengetahui pengaruh penambahan fly ash, dodol plastik, mille scale dan superplasticizer terhadap kuat lentur beton. Beton direncanakan dengan $f_{c}$ 29,05 atau K-350 dengan perbandingan limbah fly ash sebanyak $10 \%$ dari berat semen, limbah dodol plastik sebanyak 0,15\%, 0,25\% dan $0,35 \%$ dari berat pasir, mill scale $5 \%$ dari berat pasir dan superplasticizer sebanyak $2 \%$ dari berat air. Pengujian sampel pada umur 7, 14, 28 hari, untuk mengetahui kekuatan tekan dan kuat lentur dengan mengkonversi dari hasil kuat tarik belah beton dan absorpsi.
\end{abstract}

Kata kunci: Perkerasan Jalan Beton, Superplasticizer

\section{PENDAHULUAN}

Infrastruktur jalan merupakan kebutuhan manusia terutama sebagai jalur penghubung, baik itu struktur jalan secara sempurna maupun yang sangat sederhana sekali yakni berupa jalan setapak. Secara umum jalan diklasifikasikan dalam dua golongan yaitu jalan dengan perkerasan lentur dan jalan dengan perkerasan kaku. Kedua jenis perkerasan tersebut dibedakan berdasarkan material yang digunakan. Perbedaannya, perkerasan lentur umumnya menggunakan aspal sebagai material utamanya, sedangkan perkerasan kaku menggunakan beton sebagai material utamanya. 
Sebagai salah satu jenis bahan konstruksi perkerasan jalan atau jembatan, beton memiliki beberapa kelebihan sifat fisik bila dibandingkan dengan jenis bahan lain seperti misalnya aspal beton. Sifat yang dimaksud adalah sifat kekuatan dan kekakuan yang tinggi sehingga memungkinkan untuk menahan beban yang lebih besar, serta sifat keawetan (durability) yang memungkinkan biaya pemeliharaan yang lebih rendah. Di sisi lain, beton juga memiliki kelemahan yaitu kurang kuat terhadap tarik atau lentur sehingga rentan terhadap retak serta kurang memberikan kenyamanan bagi pengguna jalan atau jembatan akibat kekakuan bahan, adanya sambungan - sambungan dan adanya suara yang lebih bising saat dilalui lalu lintas dibandingkan dengan suara di atas bahan yang lebih lentur karena sifat bahannya yang tidak dapat meredam suara atau kebisingan. Oleh karena itu perlu adanya suatu alternatif untuk mendapatkan beton yang dapat memenuhi kriteria kekuatan, keawetan (durability), lebih tahan terhadap retak dan memberi tingkat kenyamanan yang cukup bagi pengendara.

Plastik merupakan bahan yang memiliki tingkat fleksibilitas yang tinggi, sehingga diduga, apabila bahan plastik ditambahkan ke dalam campuran beton akan menghasilkan beton yang memiliki regangan yang lebih besar dibandingkan beton normal tanpa penambahan bahan plastik. Permasalahannya adalah dengan adanya bahan plastik dalam campuran beton dapat menurunkan kekuatan beton. Jadi, untuk dua kondisi yang saling berseberangan tersebut perlu dilakukan suatu studi yang seksama untuk mendapatkan beton dengan penambahan bahan yang bersifat lentur, seperti plastik, tetapi tetap memenuhi nilai kekuatan minimal menurut persyaratan struktur (pavement rigid) yaitu dengan penambahan mill scale, superplasticizer dan fly ash untuk membantu tambah kuat lentur suatu beton tersebut.

Adapun tujuan dari penelitian yang dilakukan adalah sebagai berikut :

1. Untuk mengetahui nilai Slump Test (workability) beton segar dengan penambahan dodol plastik sebanyak $0 \%, 0,15 \%, 0,25 \%, 0,35 \%$ dari jumlah pasir dan mille scale $5 \%$, fly ash $10 \%$ dari jumlah semen dan admixture superplasticizer sebanyak $2 \%$ dari jumlah air.

2. Untuk mengetahui hasil uji kuat tekan, uji kuat tarik belah dan nilai absorbsi beton yang menggunakan dodol plastik $0 \%, 0,15 \%, 0,25 \%, 0,35 \%$ dari jumlah pasir dan mille scale $5 \%$, fly ash $10 \%$ dari jumlah semen dan admixture superplasticizer sebanyak $2 \%$ dari jumlah air.

3. Untuk mengetahui perbandingan beton normal dengan beton penambahan dodol plastik sebanyak $0 \%, 0,15 \%, 0,25 \%, 0,35 \%$ dari jumlah pasir dan mille scale $5 \%$, fly ash $10 \%$ dari jumlah semen dan admixture superplasticizer sebanyak $2 \%$ dari jumlah air dan dengan beton variasi tanpa (superplasticizer).

\section{METODE PENELITIAN}

Penelitian laboratorium yang dilakukan meliputi pengujian persyaratan material bahan beton, kuat tekan beton dan kuat tarik belah beton, nilai slump test (workability) dan absorbsi.

Penjelasan langkah-langkah penelitian sebagai berikut :

A. Tahap Persiapan

1. Studi Literatur

Pada tahap ini dilakukan pencarian referensi-referensi penelitian yang berhubungan dengan penelitian yang akan dilaksanakan.

2. Persiapan Alat dan Material 
Persiapan peralatan yang akan digunakan dan pengujian material utama, pembuatan yang akan dilaksanakan di Lab. Beton STT PLN.

B. Tahap Pelaksanaan

1. Pembuatan Sampel Penelitian

Pembuatan sampel untuk penelitian ini sebanyak 52 sampel dengan variasi campuran dodol plastik sebanyak $0,15 \%, 0,25 \%, 0,35 \%$ dari jumlah pasir dan mill scale 5\%, fly ash $10 \%$ dari jumlah semen dan admixture superplasticizer sebanyak $2 \%$. Pengujian sampel pada umur 7, 14, 28 hari, untuk mengetahui kekuatan tekan dan kuat tarik belah beton yang dikonversi menjadi kuat lentur, absorbsi dan slump test.

2. Pelaksanaan Pengujian Dan Pengumpulan Data

Tahap ini merupakan tahap melakukan pengujian tiap sampel yang sudah dibuat yang kemudian dicatat hasilnya padaumur 7 hari, 14 hari dan 28 hari, untuk pengujian kuat tarik belah dan absorbs pada umur 28 hari.

C. Tahap Analisa

Setelah didapatkan data hasil pengujian kemudian dilakukan analisa dan pembahasan serta membandingkan dengan beton normal untuk mengetahui nilai slump test, absorsi, kuat tekan, kuat tarik belah dan kuat lentur beton.

D. Kesimpulan dan Saran

Dari hasil analisis dan pembahasan akan ditarik kesimpulan berupa kuat tekan dan kuat tarik belah serta setting time yang tertinggi maupun yang terendah dari variasi campuran tersebut.

\section{Kuat Tarik Belah}

Menentukan tarik dalam beton dengan cara langsung lebih sulit dilakukan, oleh karena itu dikembangan cara pengujian kuat tarik tidak langsung. Besarnya tegangan tarik tidak langsung yang dialihkan saat beton itu belah, dapat dihitung menggunakan rumus :

$$
\mathrm{f}_{\mathrm{ct}}=\frac{2 \cdot P}{\pi \cdot L \cdot D}
$$

Dimana :

$\mathrm{P}=$ Beban $(\mathrm{kg})$

$\mathrm{D}=$ Diameter silinder $(\mathrm{mm})$

$\mathrm{L}=$ Panjang silinder $(\mathrm{mm})$

\section{Kuat Lentur}

Untuk mengetahui kuat lentur suatu beton, peneliti mengkonversi hasil uji kuat tarik belah ke dalam kuat lentur berdasarkan acuan Pd T-14-2003 yakni tentang perencanaan perkerasan jalan beton semen. Dalam Pd T-14-2003 dijelaskan bahwa kuat tarik lentur dapat juga ditentukan dari hasil uji kuat tarik belah beton yang dilakukan menurut SNI 03-24911991 sebagai berikut :

$$
\begin{array}{ll}
f_{c f}=1,37 . f_{c t} & \text { dalam Mpa } \\
f_{c f}=13,44 . f_{c t} & \text { dalam } \mathrm{kg} / \mathrm{cm}^{2}
\end{array}
$$

Dimana : 
$\mathrm{f}_{\mathrm{ct}}=$ kuat tarik belah beton umur 28 hari

\section{Kuat Tekan}

Nilai kuat tekan beton didapat dari pengujian standar dengan benda uji yang lazim digunakan berbentuk silinder. Persamaan yang digunakan dalam menentukan nilai kuat tekan beton adalah :

Dimana :

$$
\mathrm{K}=\frac{P}{A}
$$

$$
\begin{aligned}
& \mathrm{K}=\text { kuat tekan beton }(\mathrm{MPa}) \\
& \mathrm{P}=\text { Beban hancur }(\mathrm{N}) \\
& \mathrm{A}=\text { Luas silinder }\left(\mathrm{mm}^{2}\right)
\end{aligned}
$$

\section{Absorbsi}

Penyerapan merupakan kemampuan air untuk bergerak melalui rongga-rongga kapiler melalui permukaan hingga lapisan dalam pada beton ketika benda tersebut bersentuhan dengan air. Pengujian ini dilakukan berdasarkan SNI 03-6433-2000, tentang tata cara perhitungan pengujian penyerapan air (absorbsi) digunakan persamaan sebagai berikut :

$$
\text { Absorbsi }=\frac{B-A}{A} \times 100 \%
$$

Dimana :

$\mathrm{A}=$ berat benda uji kering $(\mathrm{kg})$

$\mathrm{B}=$ berat benda uji setelah direndam $(\mathrm{kg})$

\section{HASIL DAN PEMBAHASAN}

\section{Pengujian Agregat Halus (Pasir)}

Agregat halus (pasir) yang digunakan dalam penelitian ini adalah pasir Bangka, secara umum mutu pasir Bangka telah memenuhi syarat untuk dapat digunakan sebagai bahan bangunan.

\section{Analisa Gradasi Pasir}

Modulus kehalusan pasir Bangka yaitu 1,811\% termasuk mempunyai tingkat kehalusan pasir halus dan memenui syarat yang ditetapkan SNI 03-6820-2002 yakni dengan modulus kehalusan pasir 1,5\% - 3,8\%.

Tabel 1. Hasil Pengujian Analisis Gradasi Pasir

\begin{tabular}{|c|c|c|c|c|}
\hline $\begin{array}{c}\text { Lubang } \\
\text { Ayakan } \\
(\mathbf{m m})\end{array}$ & $\begin{array}{c}\text { Berat } \\
\text { Tinggal } \\
(\mathbf{g r})\end{array}$ & $\begin{array}{c}\text { Persen } \\
\text { Tinggal } \\
(\mathbf{\%})\end{array}$ & $\begin{array}{c}\text { Persen } \\
\text { Kumulatif } \\
(\mathbf{\%})\end{array}$ & $\begin{array}{c}\text { Persen Kumulatif } \\
\text { Lewat Ayakan } \\
(\boldsymbol{\%})\end{array}$ \\
\hline 9,5 & 0 & 0 & 0 & 100 \\
\hline 4,75 & 3 & 0,31 & 0,10 & 99,90 \\
\hline 2,36 & 5 & 0,52 & 0,62 & 99,28 \\
\hline 1,18 & 30 & 3,12 & 3,74 & 95,54 \\
\hline 0,6 & 118 & 12,27 & 16,00 & 79,54 \\
\hline 0,3 & 459 & 47,71 & 63,72 & 15,82 \\
\hline 0,15 & 320 & 33,26 & 96,98 & 3,02 \\
\hline Pan & 27 & 2,81 & - & - \\
\hline Jumlah & 962 & & 181,16 & Jumlah \\
\hline
\end{tabular}


Hasil analisa gradasi Bangka termasuk zona 4 yaitu masuk kategori pasir halus seperti terlihat pada Tabel 2 dan Gambar 1 :

Tabel 2. Batas dan Hasil Pengujian Gradasi Pasir

\begin{tabular}{|c|c|c|c|c|c|}
\hline \multirow{2}{*}{$\begin{array}{c}\text { Lubang } \\
\text { Ayakan } \\
(\mathbf{m m})\end{array}$} & \multicolumn{5}{|c|}{ \% Berat Butir Yang Lewat Ayakan } \\
\hline & $\begin{array}{c}\text { Kasar } \\
\text { (Zona I) }\end{array}$ & $\begin{array}{c}\text { Agak Kasar } \\
\text { (Zona II) }\end{array}$ & $\begin{array}{c}\text { Agak Halus } \\
\text { (Zona III) }\end{array}$ & $\begin{array}{c}\text { Halus } \\
\text { (Zona IV) }\end{array}$ & $\begin{array}{c}\text { Pasir } \\
\text { Bangka }\end{array}$ \\
\hline 9,6 & 100 & 100 & 100 & 100 & 100 \\
\hline 4,8 & $90-100$ & $90-100$ & $90-100$ & $95-100$ & 99,90 \\
\hline 2,4 & $60-95$ & $75-100$ & $85-100$ & $95-100$ & 99,28 \\
\hline 1,2 & $30-75$ & $55-90$ & $75-100$ & $90-100$ & 95,54 \\
\hline 0,6 & $15-34$ & $33-59$ & $60-79$ & $80-100$ & 79,54 \\
\hline 0,3 & $5-20$ & $8-30$ & $12-40$ & $15-100$ & 15,82 \\
\hline 0,15 & $0-10$ & $0-10$ & $0-10$ & $0-15$ & 3,02 \\
\hline
\end{tabular}

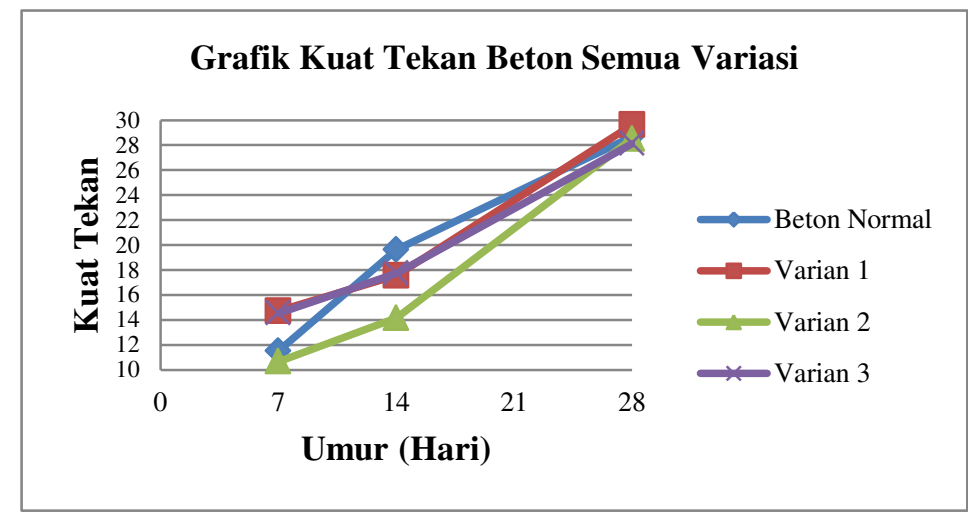

Gambar 1. Grafik Hasil Pengujian Gradasi Pasir

2. Kandungan Lumpur Dalam Pasir

Kandungan lumpur pada pasir Bangka sebesar 1,482 \%. Kandungan lumpur dalam pasir ini memenuhi syarat yang ditetapkan menurut SNI 03-6820-2002 yakni kandungan lumpur dalam pasir maksimal $5 \%$.

Tabel 3. Hasil Data Kandungan Lumpur Dalam Pasir

\begin{tabular}{|c|l|c|}
\hline No & \multicolumn{1}{|c|}{ Keterangan } & Hasil \\
\hline 1 & Berat wadah $\left(\mathrm{W}_{1}\right)$ & $340 \mathrm{gr}$ \\
\hline 2 & Berat benda uji + wadah $\left(\mathrm{W}_{2}\right)$ & $1140 \mathrm{gr}$ \\
\hline 3 & Berat benda uji $\left(\mathrm{W}_{3}\right)$ & $500 \mathrm{gr}$ \\
\hline 4 & Berat kering benda uji setelah di oven + wadah $\left(\mathrm{W}_{4}\right)$ & $1132,7 \mathrm{gr}$ \\
\hline 5 & Berat kering benda uji setelah di oven $\left(\mathrm{W}_{5}\right)$ & $492,7 \mathrm{gr}$ \\
\hline 6 & $\%$ Kadar lumpur pasir & $1,482 \%$ \\
\hline
\end{tabular}

3. Berat Jenis Pasir dan Penyerapan Air

Berdasarkan hasil pengujian berat jenis pasir dan penyerapan air menunjukkan bahwa rata-rata berat jenis kering pasir Bangka yang didapatkan dalam pengujian sebesar 2,519 dan untuk rata-rata berat jenis dalam kondisi SSD (Saturated Surface Dry) yang 
didapatkan sebesar 2,535. Sedangkan, rata-rata hasil pengujian penyerapan air sebesar $1,901 \%$.

Tabel 4. Hasil Data Berat Jenis Pasir dan Penyerapan Air

\begin{tabular}{|c|l|c|c|}
\hline No. & \multicolumn{1}{|c|}{ Keterangan } & Sample I & Sample II \\
\hline A & Berat pasir (S) & $550 \mathrm{gr}$ & $550 \mathrm{gr}$ \\
\hline B & Berat pasir setelah dikeringkan $(\mathrm{A})$ & $544,2 \mathrm{gr}$ & $548,5 \mathrm{gr}$ \\
\hline C & Berat air + piknometer $(\mathrm{B})$ & $678 \mathrm{gr}$ & $678 \mathrm{gr}$ \\
\hline D & Berat piknometer $+500 \mathrm{gr}$ pasir + air $(\mathrm{C})$ & $1012,1 \mathrm{gr}$ & $1010 \mathrm{gr}$ \\
\hline E & Berat jenis kering $\left(\frac{A}{(B+S)-c}\right)$ & 2,521 & 2,516 \\
\hline F & Saturated Surface Dry $(\mathrm{SSD})\left(\frac{S}{(B+S)-C}\right)$ & 2,547 & 2,523 \\
\hline G & \% Penyerapan $\left(\frac{S-A}{A} x 100 \%\right)$ & $1,066 \%$ & $2,735 \%$ \\
\hline H & Rata - rataberat jeniskering & \multicolumn{2}{|c|}{2,519} \\
\hline I & Rata - rata Saturated Surface Dry(SSD) & \multicolumn{2}{|c|}{$1,901 \%$} \\
\hline J & Rata - rata \% penyerapan & \multicolumn{2}{|c|}{} \\
\hline
\end{tabular}

\section{Pengujian Agregat Kasar (Kerikil)}

a. Analisis Gradasi Keriki/Kasar

Berdasarkan hasil dari pengujian analisis gradasi kerikil dari Bogor ini menunjukkan bahwa mempunyai bentuk ukuran yang bervariasi dengan ukuran maksimal $40 \mathrm{~mm}$. Hasil untuk modulus kehalusan yang didapat sebesar 6,31\% dimana nilai modulus kehalusan tersebut memenuhi syarat menurut SNI 03-2461-2014 yakni nilai modulus kehalusan tidak lebih dari $6 \%-7,15 \%$ dan kerikil dari Bogor ini dapat digunakan sebagai material utama campuran beton.

Tabel 5. Hasil Pengujian Analisis Gradasi Kerikil

\begin{tabular}{|c|c|c|c|c|}
\hline $\begin{array}{l}\text { Lubang Ayakan } \\
(\mathrm{mm})\end{array}$ & $\begin{array}{l}\text { Berat Tinggal } \\
(\mathrm{gr})\end{array}$ & $\begin{array}{c}\text { Persen } \\
\text { Tinggal }(\%) \\
\end{array}$ & $\begin{array}{c}\text { Persen Kumulatif } \\
(\%)\end{array}$ & $\begin{array}{r}\text { Persen Kumulatif } \\
\text { Lewat Ayakan (\%) }\end{array}$ \\
\hline 37,5 & 200 & 4,00 & 4,00 & 96,00 \\
\hline 25,0 & 600 & 12,00 & 16,00 & 84,00 \\
\hline 19,0 & 1515 & 30,30 & 46,30 & 53,70 \\
\hline 12,5 & 1522 & 30,44 & 76,74 & 23,26 \\
\hline 9,5 & 605 & 12,10 & 88,84 & 11,16 \\
\hline 4,75 & 558 & 11,16 & 100,00 & 0 \\
\hline 2,36 & 0 & 0 & 100,00 & 0 \\
\hline 1,18 & 0 & 0 & 100,00 & 0 \\
\hline PAN & 0 & 0 & 100,00 & 0 \\
\hline Jumlah & 5000 & & 631,88 & \\
\hline \multicolumn{4}{|c|}{ FM : Modulus Kehalusan Kerikil $=\frac{\text { Jumlah } \% \text { komulatif yang tertinggal }}{100}$} & 6,31 \\
\hline
\end{tabular}

Tabel 6. Syarat Batas dan Hasil Gradasi Kerikil

\begin{tabular}{|c|c|c|c|c|}
\hline \multirow{2}{*}{$\begin{array}{c}\text { Ukuran Lubang } \\
\text { Ayakan } \\
(\mathrm{mm})\end{array}$} & \multicolumn{4}{|c|}{ Persentase Berat Bagian Yang Lewat Ayakan } \\
\cline { 2 - 5 } & \multicolumn{3}{|c|}{ Ukuran Nominal Agregat (mm) } & Hasil Gradasi Kerikil \\
\cline { 2 - 5 } & $\mathbf{4 0}$ & 20 & 10 & $\mathbf{4 0}$ \\
\hline 38,1 & $\mathbf{9 5}-\mathbf{1 0 0}$ & 100 & - & $\mathbf{9 6 , 0 0}$ \\
\hline 19,0 & $\mathbf{3 7}-\mathbf{7 0}$ & $95-100$ & 100 & $\mathbf{5 3 , 7 0}$ \\
\hline 9,52 & $\mathbf{1 0}-\mathbf{4 0}$ & $30-60$ & $50-85$ & $\mathbf{1 1 , 1 6}$ \\
\hline 4,76 & $\mathbf{0}-\mathbf{5}$ & $0-10$ & $0-10$ & $\mathbf{0}$ \\
\hline
\end{tabular}




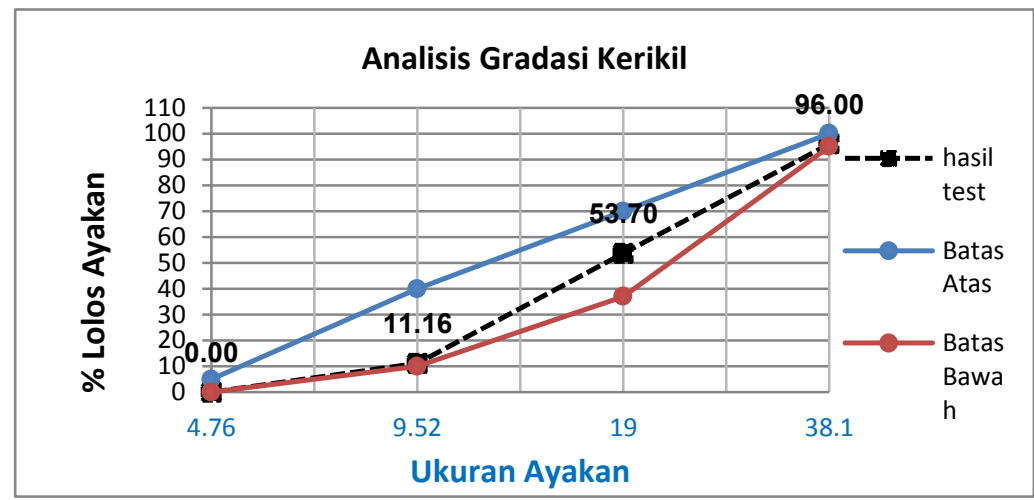

Gambar 2. Grafik Pengujian Analisis Gradasi Kerikil

b. Berat Jenis Kerikil dan Penyerapan Air

Berdasarkan hasil pengujian berat kerikil dan penyerapan air menunjukkan bahwa ratarata berat jenis kering kerikil sebesar 2,622, sedangkan rata-rata berat jenis kondisi Saturated Surface Dry (SSD) sebesar 2,686 dan penyerapan air sebesar 2,40\%.

Tabel 7. Hasil Pengujian Berat Jenis Kerikil dan Penyerapan Air

\begin{tabular}{|c|l|c|c|}
\hline No. & \multicolumn{1}{|c|}{ Keterangan } & Sample I & Sample II \\
\hline A & Berat agregat kasar & $3000 \mathrm{gr}$ & $3000 \mathrm{gr}$ \\
\hline B & $\begin{array}{l}\text { Berat agregat kasar setelah } \\
\text { dikeringkan }\end{array}$ & $2931 \mathrm{gr}$ & $2925 \mathrm{gr}$ \\
\hline C & Berat agregat kasar dalam air & $1882 \mathrm{gr}$ & $1884 \mathrm{gr}$ \\
\hline D & Berat jenis agregat kasar $\left(\frac{\square}{\square-\square}\right)$ & 2,622 & 2,621 \\
\hline E & $\begin{array}{l}\text { Saturated Surface Dry } \\
(\mathrm{SSD})\left(\frac{\square}{\square-\square}\right)\end{array}$ & 2,683 & 2,688 \\
\hline F & $\%$ Penyerapan $\left(\frac{\square-\square}{\square} \square 100 \%\right)$ & $2.300 \%$ & $1,500 \%$ \\
\hline G & Rata - rataberat jenis kering & \multicolumn{2}{|c|}{2,622} \\
\hline H & $\begin{array}{l}\text { Rata }- \text { rata Saturated Surface Dry } \\
\text { (SSD) }\end{array}$ & \multicolumn{2}{|c|}{2,686} \\
\hline I & Rata - rata \% penyerapan & \multicolumn{2}{|c|}{$2,400 \%$} \\
\hline
\end{tabular}

\section{Hasil Pengujian Nilai Slump Test}

Berikut ini adalah data-data hasil dari pengujian nilai slump test dari 4 variasi.

Tabel 8. Hasil Slump Test

\begin{tabular}{|l|c|}
\hline \multicolumn{1}{|c|}{ Sample } & Nilai Slump Beton (cm) \\
\hline Beton Normal & 10 \\
\hline Varian 1 (DP 0,15\% + MS 10\% + FA 10\% + SP 2\%) & 12 \\
\hline Varian 2 (DP 0,25\% + MS 10\% + FA 10\% + SP 2\%) & 11 \\
\hline Varian 3 (DP 0,35\% + MS 10\% FA 10\% + SP 2\%) & 11,5 \\
\hline
\end{tabular}


Nilai slump test yang ditentukan berkisar $80 \mathrm{~mm}-130 \mathrm{~mm}$ termasuk slump plastis. Adanya perbedaan hasil slump yang ditunjukkan oleh sampel beton normal dengan slump 10 $\mathrm{cm}$ dan beton variasi dengan slump $12 \mathrm{~cm}-11 \mathrm{~cm}$ disebabkan adanya penambahan superplasticizer sebanyak $2 \%$ dari berat air mampu memberikan kelecekan yang panjang pada beton. Sehingga beton menjadi lebih plastis dan mudah dikerjakan.

\section{Hasil Pengujian Kuat Tekan Beton}

Berikut adalah hasil uji rata-rata kuat tekan semua beton variasi dalam satuan MPa.

Tabel 9. Hasil Rata-Rata Kuat Tekan Beton Semua Variasi

\begin{tabular}{|c|c|c|c|c|}
\hline $\begin{array}{c}\text { Umur } \\
\text { Pengujian }\end{array}$ & $\begin{array}{c}\text { Varian Normal } \\
\text { (DP 0\% + MS } \\
0 \%+\text { FA 0\% + } \\
\text { SP 0\%) } \\
(\mathrm{MPa})\end{array}$ & $\begin{array}{c}\text { Varian 1 (DP } \\
0,15 \%+\text { MS } 10 \% \\
+ \text { FA } 10 \%+\text { SP } \\
2 \%) \\
(\mathrm{MPa})\end{array}$ & $\begin{array}{c}\text { Varian } 2 \text { (DP } \\
0,25 \%+\mathrm{MS} \\
10 \%+\mathrm{FA} 10 \% \\
+ \text { SP 2\%) } \\
(\mathrm{MPa})\end{array}$ & $\begin{array}{c}\text { Varian } 3(\mathrm{DP} \\
0,35 \%+\mathrm{MS} 10 \% \\
\text { FA } 10 \%+\text { SP 2\%) } \\
(\mathrm{MPa})\end{array}$ \\
\hline 7 Hari & 11,512 & 14,720 & 10,663 & 14,532 \\
\hline 14 Hari & 19,627 & 17,551 & 14,154 & 17,740 \\
\hline 28 Hari & 28,686 & 29,630 & 28,498 & 28,120 \\
\hline
\end{tabular}

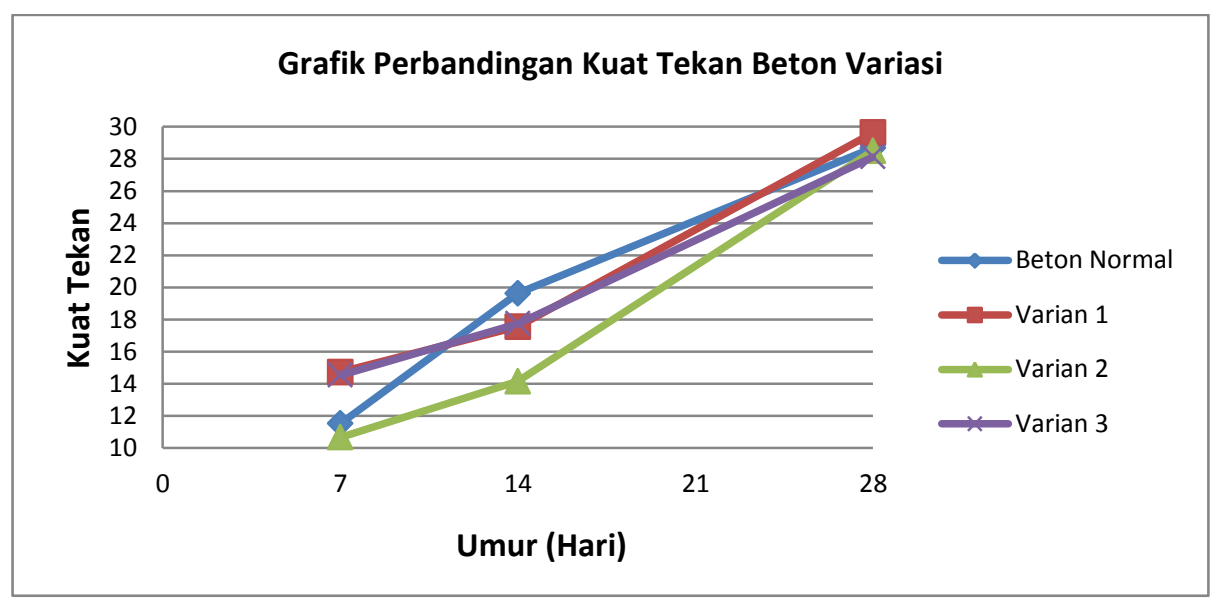

Gambar 3. Grafik Hasil Kuat Tekan Beton Semua Variasi

Dari Tabel 9 dan Gambar 3 di atas dapat diketahui bahwa untuk sampel beton variasi 1 yaitu dengan campuran dodol plastik $0,15 \%$ + Mile Scale $10 \%+$ fly ash $10 \%+$ superplasticizer $2 \%$ mempunyai kuat tekan yang paling tinggi yakni sebesar 29,630 MPa pada saat umur 28 hari. Sedangkan beton normal mempunyai kuat tekan sebesar 28,686 $\mathrm{MPa}$, maka beton variasi 1 memperoleh kenaikan sebesar 3,29\% dengan selisih 0,944 MPa.

\section{Hasil Pengujian Kuat Tarik Beton Dan Konversi Menjadi Kuat Lentur}

Berikut adalah tabel dan grafik hasil pengujian kuat tarik beton :

Tabel 10. Hasil Rata-Rata Kuat Tarik Beton Semua Variasi

\begin{tabular}{|c|c|c|c|c|c|c|}
\hline No & Variasi Campuran & $\begin{array}{c}\text { Umur } \\
(\text { Hari })\end{array}$ & $\begin{array}{c}\text { Luas }(\pi \mathrm{LD}) \\
\left(\mathrm{mm}^{2}\right)\end{array}$ & $\begin{array}{c}\text { Beban } \\
(\mathrm{kN})\end{array}$ & $\begin{array}{c}\text { Kuat Tarik } \\
(\mathrm{MPa})\end{array}$ & $\begin{array}{c}\text { Kuat Lentur } \\
(\mathrm{MPa})\end{array}$ \\
\hline 1 & Beton Normal & 28 & 141371,669 & 126,67 & 1,792 & 2,455 \\
\hline 2 & Beton Variasi 1 & 28 & 141371,669 & 136,67 & 1,267 & 1,735 \\
\hline 3 & Beton Variasi 2 & 28 & 141371,669 & 91,67 & 1,267 & 1,777 \\
\hline 4 & Beton Variasi 3 & 28 & 141371,669 & 106,67 & 1,509 & 2,067 \\
\hline
\end{tabular}


Dari Tabel 10 di atas dapat diketahui bahwa untuk sampel beton variasi 3 yaitu dengan campuran dodol plastik $0,35 \%$ + Mile scale $10 \%+$ fly ash $10 \%+$ superplasticizer $2 \%$ mempunyai kuat tarik yakni sebesar 1,509 MPa pada saat umur 28 hari, dengan kuat lenturnya 2,067 MPa. Sedangkan beton normal mempunyai kuat tarik terbesar 1,792 $\mathrm{MPa}$ dengan kuat lenturnya 2,455 $\mathrm{MPa}$, maka beton variasi 3 memperoleh penurunan sebesar 28,3\% dengan selisih 0,283 $\mathrm{MPa}$ dengan penurunan kuat lentur 38,8 \% atau selisih 0,388 MPa. Hal ini disebabkan pengaruh dari oli yang mempengaruhi daya lekat.

\section{Hasil Pengujian Absorbsi Beton}

Pengujian absorbsi dilakukan pada saat umur beton 28 hari, berdasarkan SNI 03-64332000.

Tabel 11. Hasil Uji Absorbsi

\begin{tabular}{|c|l|c|c|c|}
\hline No & Variasi Campuran & $\begin{array}{c}\text { Berat Setelah Direndam } \\
(\mathbf{k g})\end{array}$ & $\begin{array}{c}\text { Berat Kering } \\
(\mathbf{k g})\end{array}$ & $\begin{array}{c}\text { Absorbsi } \\
(\mathbf{\%})\end{array}$ \\
\hline 1 & Beton Normal & 12,58 & 12,26 & 2,61 \\
\hline 2 & Beton Variasi 1 & 12,66 & 12,30 & 2,93 \\
\hline 3 & Beton Variasi 2 & 12,60 & 12,34 & 2,11 \\
\hline 4 & Beton Variasi 3 & 12,26 & 11,84 & 3,55 \\
\hline
\end{tabular}

Dari Tabel 11 di atas dapat diketahui bahwa hasil absorbsi untuk sampel beton variasi 3 yakni dengan campuran dodol plastik $0,35 \%+$ fly ash $10 \%+$ superplasticizer $2 \%$ mempunyai penyerapan yang paling tinggi yakni sebesar 3,55\%. Sedangkan beton normal yang mempunyai penyerapan sebesar $2,61 \%$.

\section{KESIMPULAN DAN SARAN}

Berdasarkan hasil penelitian dan analisa dapat diambil kesimpulan dari hasil pengujian yaitu limbah PLTSa berupa dodol plastik dapat digunakan untuk bahan tambah dalam campuran beton dengan maksimum kadar dodol plastik yang baik tidak lebih 0,35\% dari berat pasir. Penyerapan air dalam beton tertinggi pada variasi 3 sebesar 3,55\% dibandingkan beton normal dengan selisih $0,94 \%$. Beton Variasi 1 mempunyai kuat tekan tertinggi yakni sebesar 29,63 MPa dengan campuran dodol plastik $0,15 \%+$ fly ash $10 \%+$ superplasticizer $2 \%$, dibandingkan dengan beton normal sebesar 28,686 MPa dengan kenaikan 3,28\%. Kuat tarik belah beton tertinggi yaitu variasi 3 sebesar 1,509 MPa dengan konversi menjadi kuat lentur sebesar 2,067 MPa.

Beberapa saran terkait dengan hasil penelitian yang telah dilaksanakan adalah untuk memaksimalkan hasil kuat tarik belah pada penelitian lanjutan, dapat dilakukan pengolahan lebih lanjut terhadap bahan tambah dodol plastik karena mengandung oli. Perlu adanya percobaan memakai tambahan dodol plastik dengan variasi bentuk dimana panjang dan diameternya dibedakan agar memaksimalkan hasil kuat lentur yang didapat.

\section{DAFTAR PUSTAKA}

[1] Badan Standarisasi Nasional. (1991). SNI 03-2460-1991 Spesifikasi Abu Terbang Sebagai Bahan Tambahan untuk Campuran Beton. Bandung. Badan Standarisasi Nasional

[2] Badan Standarisasi Nasional. (1990). SNI03-1968-1990 Metode Pengujian Analisis Saringan Agregat Halus dan Kasar. Bandung. Badan Standarisasi Nasional. 
[3] Badan Standarisasi Nasional. (2008). SNI1970-2008 Cara Uji Berat Jenis Dan Penyerapan Air Agregat Halus. Bandung : Badan Standarisasi Nasional.

[4] Badan Standarisasi Nasional. (2008). SNI 1972-2008 Cara Uji Slump Beton. Bandung. Badan Standarisasi Nasional.

[5] Badan Standarisasi Nasional. (2011). SNI 1974-2011 Cara Uji Kuat Tekan Beton Dengan Benda Uji Silinder. Bandung.Badan Standarisasi Nasional.

[6] Eldin, Zaher, Serge ,dan Smith et.,al (1995). Penelitian Kekuatan Beton dengan Menambahkan Karet kedalam Campuran Beton. Jakarta.

[7] Kardiyono Tjokrodimuljo,Ir,M.E. (2007). Teknologi Beton. Yogyakarta : Biro Penerbit.

Mardiono. (2011). Pengaruh Pemanfaatan Abu Terbang (Fly Ash) Dalam Beton Mutu Tinggi. Skripsi. Sarjana. Teknik Sipil. Universitas Gunadarma Jakarta. 